\title{
Perbedaan Akhlak Ditinjau dari Kecerdasan Emosional dan Kecerdasan Spiritual Siswa SMP Negeri se-Kecamatan Sidoharjo Tahun Ajaran $2020 / 2021$
}

\author{
Abdul Wahid ${ }^{*}$, Retno Wahyuningsih ${ }^{1}$ \\ IAIN Surakarta, Indonesia \\ *48sidoel@mail.com
}

\begin{abstract}
Abstrak
Penelitian ini bertujuan untuk mengetahui: 1) Perbedaan akhlak antara kecerdasan emosional tinggi dan rendah . 2) Perbedaan akhlak antara kecerdasan spiritual tinggi dan rendah. 3) Perbedaan akhlak ditinjau dari interaksi antara kecerdasan emosional dan kecerdasan spiritual pada siswa di SMP Negeri Se-Kecamatan Sidoharjo tahun ajaran 2020/2021. Metode penelitian yang digunkanan adalah kuantitaif komparatif dengan menggunakan analisis uji t dan anova dua jalur di SMP Negeri se-Kecamatan Sidoharjo pada bulan Oktober sampai dengan Desember 2020. Popilasi dalam penelitian ini adalah selueuh kelas siswa kelas VIII Sebanyak 507 siswa. Sampel adalah Sebagian siswa SMP Negeri se-Kecamatan Sidoharjo sebanyak 221 siswa. Hasil penelitian menunjukan : 1) terdapat perbedaan akhlak antara siswa yang memiliki kecerdasan emosional tinggi dan rendah, karena diperoleh nilai signifikansi sebesar $0.000<0,05.2$ ) terdapat perbedaan akhlak antara siswa yang memiliki kecerdaan spiritual tinggi dan rendah karena diperoleh nilai signifikansi sebesar $0.000<0,05.3$ ) terdapat perbedaan akhlak ditinjau dari interaksi kecerdasan emosional dan kecerdasan spiritual, hasil hipotesis menunjukan sig. $0.001<0.05$. terdapat interaksi antara kecerdasan emosional tinggi dan kecerdasan spiritual rendah, kecerdasan spiritual tinggi dan kecerdasan emosional rendah terhadap akhlak.
\end{abstract}

Kata kunci: Akhlak, kecerdasan emosional, kecerdasan spiritual

\begin{abstract}
This study aims to determine: 1) The difference in akhlak between high and low emotional intelligence. 2) The difference in akhlak between high and low spiritual intelligence. 3) Moral differences in terms of the interaction between emotional intelligence and spiritual intelligence in students of SMP Negeri Sidoharjo in the academic year 2020/2021. The research method used was comparative quantitative using t-test analysis and two-way ANOVA at State Junior High Schools in Sidoharjo District from October to December 2020. The population in this study were all classes of grade VIII students totaling 507 students. The sample is some students of SMP Negeri in Sidoharjo District as many as 221 students. The results showed: 1) there is a difference in akhlak between students who have high and low
\end{abstract}




\section{Wahid \& Wahyuningsih}

emotional intelligence, because the significance value is $0.000<0.05$. 2) there are moral differences between students who have high and low spiritual intelligence because the significance value is 0.000 $<0.05$. 3) there are differences in akhlak in terms of the interaction between emotional intelligence and spiritual intelligence, the hypothesis results show sig. $0.001<0.05$. there is an interaction between high emotional intelligence and low spiritual intelligence, high spiritual intelligence and low emotional intelligence towards akhlak.

Keywords : Akhlak, emotional intelligence, spiritual intelligence

\section{Pendahuluan}

Pendidikan merupakan usaha sadar dan terencana untuk mewujudkan suasana belajar dan proses pembelajaran supaya peserta didik secara aktif mengembangkan potensi dirinya untuk memiliki kekuatan spiritual keagamaan, pengendalian diri, kepribadian, kecerdasan, akhlak mulia serta keterampilan yang diperlukan dirinya, masyarakat, bangsa dan Negara (Suardi, 2012:71). Menurut Basri (2013:15) pendidikan adalah usaha yang dilakukan secara sengaja dan sistematis untuk membimbing, membina, memotivasi dan membantu seseorang untuk mengembangkan segala potensinya sehingga tecapai kualitas diri yang lebih baik. Inti dari pendidikan adalah usaha pendewasaan manusia seutuhnya (lahir dan batin) agar memiliki kemerdekaan berfikir, bertindak serta percaya diri dengan penuh rasa tanggung jawab dalam setiap tindakan dan perilakunya dalam kehidupan sehari-hari. Peserta didik tidak hanya diharapkan bertambah pengetahuan dan wawasannya, tetapi juga meningkatkan kecakapan dan keterampilannya serta semakin mulia karakter kepribadiannya serta akhlak dan budi pekerti yang luhur (Kemendikbud: 2014).

Kegiatan belajar pada pendidikan formal diharapkan terjadi perubahan yang bersifat positif sehingga pada tahap akhir akan mempunyai keterampilan, kecakapan, pengetahuan dan akhlak yang baik sebagai bekal mengarungi hidup di masyarakat. Ibnu Miskawai mengemukakan Akhlak adalah sifat yang tertanam dalam jiwa yang mendorongnya untuk melakukan perbuatan tanpa memerlukan pemikiran dan pertimbangan (Ichwan, 2007:256). Fenomena tawuran, seks di luar pernikahan dan didorong semakin maraknya penyebaran situs porno, dan penggunaan narkoba serta minuman alkohol. Selain persoalan diatas terdapat krisis spiritualitas pada diri anak dan remaja. Terbukti adanya kriminalitas yang dilakukan anak-anak seperti perampokan, perjudian, pembunuhan, kecanduan narkoba, seks bebas dan, tawuran antar sekolah (berita situs detik.com:2020)

Hasil survey yang dilakukannpeneliti melalui wawancara dengan bapak Sudirman selaku guru agama islam, ditemukan siswa yang memililiki akhlak tidak baik, tidak memiliki sopan santun, berbicara kotor, tidak mengikuti jamaah sholat di sekolah, tidak mengikuti program imtaq, pacaran, meminta uang ke adik kelas dan merokok, dalam ukuran kuantitas pelanggaran akhlak di SMPN 2 Sidoharjo sudah mencapai 25\% dari seluruh jumlah siswa.

Fenomena yang terjadi di atas nampaknya sangat kontradiksi dengan rumusan Tujuan Pendidikan Nasional sebagaimana ditegaskan dalam Undang-Undang No. 20 
tahun 2003 pasal 3 bahwa "Pendidikan Nasional berfungsi mengembangkan kemampuan dan membentuk watak serta peradaban bangsa yang bermartabat dalam rangka mencerdaskan kehidupan bangsa, bertujuan untuk berkembangnya potensi peserta didik agar menjadi manusia yang beriman dan bertakwa kepada Tuhan Yang Maha Esa, berakhlak mulia, sehat, berilmu, cakap, kreatif, mandiri dan menjadi warga negara yang demokratis serta bertanggung jawab" (UU RI No 20 Tahun 2003). Menurut Djazimi (2016: 49) Perilaku merosotnya akhlak pada peserta didik dapat dipengaruhi 2 faktor yaitu faktor eksternal dan faktor internal. Faktor eksternal yang mempengaruhi akhlak siswa antara lain keluarga, sekolah dan masyarakat. Sedangkan faktor internal antara lain kecerdasan emosional dan kecerdasan spiritual peserta didik. Ary Ginanjar (2005: 62) menjelaskan kecerdasan emosional adalah sebuah kemampuan untuk mendengarkan bisikan emosi dan menjadikannya sebagai sumber informasi penting untuk memahami diri sendiri dan orang lain demi mencapai sebuah tujuan. Individu yang memiliki tingkat kecerdasan emosional yang lebih baik, dapat menjadi terampil dalam menenangkan dirinya dengan cepat, lebih terampil dalam memusatkan perhatian, lebih baik dalam berhubungan dengan orang lain, lebih cakap dalam memahami orang, dan untuk kerja akademis disekolah lebih baik (Triatna dan Kharisma, 2008: 25).

Faktor internal yang mempengaruhi akhlak selanjutnya adalah faktor kecerdasan sipritual, Menurut Zohar dan Marshall (2005: 178) kecerdasan spiritual adalah inti dari segala intelegensia. Kecerdasan ini digunakan untuk menyelesaikan masalah kaidah dan nilai-nilai spiritual. Dengan adanya kecerdasan ini, akan membawa seseorang untuk mencapai kebahagiaan yang hakiki. Menurut Zohar dan Marshall dalam Ary Ginanjar (2005:46) kecerdasan spiritual sebagai kecerdasan untuk menghadapi persoalan makna atau value, yaitu kecerdasan untuk menempatkan perilaku dan hidup kita dalam konteks makna yang lebih luas dan kaya, kecerdasan untuk menilai bahwa tindakan atau jalan hidup seseorang lebih bermakna dibandingkan dengan yang lain.

Menurut Ary Ginanjar, 2006:80) Kecerdasan spiritual (SQ), dipusatkan untuk memunculkan perasaan kasih sayang, cinta, keindahan, keadilan, kejujuran dan perilaku yang baik. Melihat pentingnya kecerdasan emosional dan spiritual terhadap pembentukan perilaku (akhlak) siswa, Seyogyanya pendidikan tidak hanya menjadikan manusia itu pandai secara intelektual (IQ) saja melainkan juga pandai dalam mengaplikasikan dan menerapkan pengetahuannya secara benar dan tepat guna, sekaligus menjadikan kepribadiannya lebih stabil, kondisional dalam berinteraksi terhadap masyarakat luas dan matang secara emosional (EQ) dan spiritualnya (SQ). .

Paradoks tersebut mengindikasikan bahwa fungsi pendidikan sebagai pembentuk kepribadian telah mengalami degradasi nilai atau sikap di dalam praktik pendidikan. Taksonomi pendidikan sebagai bingkai wilayah kepribadian manusia yakni membentuk sikap, mengembangkan pengetahuan serta melatihkan keterampilan, nampaknya belum menjadi domain yang utuh dalam tataran outcomes pendidikan. Bahkan dalam praktiknya, domain kognitif lebih dipentingkan dari pada domain yang lainnya. Seolah kepribadian manusia hanya berhubungan dengan kecerdasan otaknya, yang belakangan dikenal dengan IQ. Kecerdasan intelektual belum tentu menjadi tolak ukur kesuksesan pribadi seseorang untuk memiliki sikap yang baik (akhlak), bersosial, hidup 
dimasyarakat dan dunia kerja, kecerdasan intelektual yang tinggi hanya mempengaruhi kepribadian seseorang 20\% dan 80\% lainnya dipengaruhi oleh kecerdasan emosional dan spiritual (Goleman, 2005: 231).

Penelitian serupa dilakukan oleh M. zulkifli ( 2015) dengan judul pengaruh kecerdasan emosional dan kecerdasan spiritual terhadap prestasi belajar aqidah akhlak siswa kelas XI Madrasah Aliyah Kecamatan Suralaga kabupaten Lombok timur, perbedan dengan penelitian ini adalah pada variabel terikat yaitu prestasi belajar aqidah akhlak. Penelitian Sumikan (2011) dengan judul pengaruh kecerdasan emosional, keecerdasan spiritual dan pertasi belajar PAI siswa kelas X SMK Negeri 1 Delanggu Mojokerto, perbedaan dengan penelitian ini terdapat pada variabel terikat yaitu prestasi belajar PAI. Selanjutnya, penelitian Azizollah Arbabisarjou (2016) dengan judul hubungan antara kecerdasan spiritual dan kecerdasan emosional diantara mahasiswa ilmu kedokteran universitas Isfahan, perbedaan dengan penelitian ini terdapat pada variabel terikat (Y) yaitu peningkatan hubungan sosial.

Berbeda dengan penelitian sebelumnya, penelitian ini akan melahirkan sebuah pemahaman baru yang berkaitan tentang pengaruh kecerdasan emosional dan spiritual terhadap akhlak. Sehingga menambah pengtahuan untuk mengetahu faktor faktor yang mempengaruhi akhlak seseorang.

Penelitian ini bertujuan yaitu untuk mengetahui perbedaan akhlak antara kecerdasan emosional tinggi dan rendah, untuk mengetahui perbedaan akhlak antara kecerdasan spiritual tinggi dan rendah, dan untuk mengetahui perbedaan akhlak ditinjau dari interaksi antara kecerdasan emosional dan kecerdasan spiritual pada siswa di SMP Negeri Se-Kecamatan Sidoharjo tahun ajaran 2020/2021

\section{Metode Penelitian}

Metode penelitian yang digunakan adalah metode kuantitaif komparatif. Penelitian ini membandingkan akhlak ditinjau dari kecrdasan emosional dan kecerdasan spiritual. Penelitian komparatif menurut sugiyono (2015: 24) yaitu penelitian yang membandingkan keberadaan satu variabel atau lebih pada dua atau sampel yang berbeda, atau pada waktu yang berbeda. Penelitian ini dilakukan untuk mengetahui perbedaan akhlak di tinjau dari kecerdasan emosional dan kecerdasan spiritual siswa SMP Negeri se-Kecamatan Sidoharjo tahun ajaran 2020/2021.

Penelitian ini dilakukan di SMP Negeri se-Kecamatan Sidoharjo Kabupaten Sragen pada tahun pelajaran 2020/2021, dengan pertimbangan dimana sekolah ini siswanya cenderung memiliki akhlak yang kurang baik. Adapun penelitian ini dilaksanakan pada bulan Agustus sampai Desember 2020.

Populasi dalam penelitian ini adalah seluruh siswa kelas VIII sebanyak 507 siswa. Menurut Sugiyono (2015: 117), populasi adalah wilayah generalisasi yang terdiri atas obyek atau subyek yang mempunyai kualitas dan karakteristik tertentu yang ditetapkan oleh peneliti untuk dipelajari dan kemudian ditarik kesimpulannya. Untuk lebih jelasnya, populasi dalam penelitian ini dapat dilihat pada tabel berikut: 
Tabel 1

Jumlah Populasi

\begin{tabular}{|c|c|c|c|c|}
\hline No & Kelas & $\begin{array}{c}\text { SMP Negeri } \\
\text { Sidoharjo }\end{array}$ & $\begin{array}{l}\text { SMP } \\
\text { Sidoharjo }\end{array}$ & Jumlah \\
\hline 1 & VIII A & 32 & 30 & 62 \\
2 & VIII B & 29 & 31 & 60 \\
3 & VIII C & 32 & 32 & 64 \\
4 & VIII D & 32 & 32 & 64 \\
5 & VIII E & 32 & 26 & 58 \\
6 & VIII F & 32 & 26 & 58 \\
7 & VIII G & 32 & 26 & 58 \\
8 & VIII H & 32 & 25 & 57 \\
9 & VIII I & 26 & 26 \\
\hline \multicolumn{5}{|c}{ Jumlah } \\
\hline
\end{tabular}

Sumber: Hasil Perhitungan Populasi

Adapun sampel dari penelitian ini adalah sebagian siswa Madrasah se-Kecamatan Jumantono sebanyak 221 siswa. Jumlah sampel dihitung menggunakan rumus Slovin. Pengambilan sampel menggunakan teknik proportional stratified random sampling. Teknik sampling yang digunakan dalam penelitian ini adalah proporsional stratified random sampling dengan jumlah populasi 221 siswa. Adapun sebaran populasi dan sampel dalam kelasnya dapat dilihat pada tabel berikut :

Tabel 2 Jumlah Sampel

\begin{tabular}{|c|ccc|}
\hline No & Kelas & $\begin{array}{c}\text { Jumlah } \\
\text { Populasi }\end{array}$ & Sampel \\
\hline 1 & VIII A SMPN 1 Sidoharjo & 32 & $n=\frac{32}{507} \times 224=14$ \\
2 & VIII B SMPN 1 Sidoharjo & 29 & $n=\frac{29}{507} \times 224=13$ \\
3 & VIII C SMPN 1 Sidoharjo & 32 & $n=\frac{32}{507} \times 224=14$ \\
4 & VIII D SMPN 1 Sidoharjo & 32 & $n=\frac{32}{507} \times 224=14$ \\
5 & VIII E SMPN 1 Sidoharjo & 32 & $n=\frac{32}{507} \times 224=14$ \\
6 & VIII F SMPN 1 Sidoharjo & 32 & $n=\frac{32}{507} \times 224=14$ \\
7 & VIII G SMPN 1 Sidoharjo & 32 & $n=\frac{32}{507} \times 224=14$
\end{tabular}


Wahid \& Wahyuningsih

\begin{tabular}{cccc}
8 & VIII H SMPN 1 Sidoharjo & 32 & $n=\frac{32}{507} \times 224=14$ \\
9 & VIII I SMPN 1 Sidoharjo & 26 & $n=\frac{26}{507} \times 224=11$ \\
10 & VIII A SMPN 2 Sidoharjo & 30 & $n=\frac{32}{507} \times 224=14$ \\
11 & VIII B SMPN 2 Sidoharjo & 31 & $n=\frac{29}{507} \times 224=13$ \\
12 & VIII C SMPN 2 Sidoharjo & 32 & $n=\frac{32}{507} \times 224=14$ \\
13 & VIII D SMPN 2 Sidoharjo & 32 & $n=\frac{32}{507} \times 224=14$ \\
14 & VIII E SMPN 2 Sidoharjo & 26 & $n=\frac{32}{507} \times 224=14$ \\
15 & VIII F SMPN 2 Sidoharjo & 26 & $n=\frac{32}{507} \times 224=14$ \\
16 & VIII G SMPN 2 Sidoharjo & 26 & $n=\frac{32}{507} \times 224=14$ \\
17 & VIII H SMPN 2 Sidoharjo & 25 & $n=\frac{32}{507} \times 224=14$ \\
\hline Jumlah & & 507 & 221 \\
\hline
\end{tabular}

Sumber: Hasil Perhitungan Sampel

Dalam penelitian ini terdiri 3 variabel yaitu kecerdasan emosional (X1), kecerdasan spiritual (X2) sebagai variabel bebas, sedangkan Akhlak (Y) sebagai variabel terikat. Pengumpulan data dalam penelitian ini menggunakan angket untuk mengumpulkan data kecerdasan emosional, kecerdasan spiritual dan akhlak. Angket adalah suatu teknik pengumpulan informasi yang memungkinkan analisis mempelajari sikap-sikap, keyakinan, perilaku dan karaktristik beberapa orang utama di dalam organisasi yang bisa terpengaruh oleh sistem yang diajukan dalam proses pengumpulan data (Syofian, 2017:21). berikut :

Adapun kisi-kisi untuk penyusunan angket penelitian dapat dilihat pada tabel 3

Tabel 3

Kisi-kisi Instrumen Variabel

Kecerdasan Emosional

\begin{tabular}{|c|c|c|c|}
\hline & \multirow[b]{2}{*}{ Indicator } & & \multirow{3}{*}{$\frac{\text { jumlah }}{5}$} \\
\hline \multirow{2}{*}{$\begin{array}{c}\text { Variabel } \\
\text { Kecerdasan }\end{array}$} & & \multirow{2}{*}{$\begin{array}{c}\text { No. item } \\
1,22,15,11,1\end{array}$} & \\
\hline & 1. Kesadaran Diri & & \\
\hline \multirow{6}{*}{ Emosional } & & 2 & \\
\hline & 2. Pengaturan Diri & $2,21,17,10$ & 4 \\
\hline & $\begin{array}{l}\text { 3. Memotivasi diri } \\
\text { sendiri }\end{array}$ & $3,20,16,8$ & 4 \\
\hline & 4. Empati & $4,18,14,7$ & 4 \\
\hline & $\begin{array}{l}\text { 5. Keterampilan } \\
\text { sosial }\end{array}$ & $5,19,13,6,9$ & 5 \\
\hline & Total & & 22 \\
\hline
\end{tabular}




\section{Kecerdasan Spiritual}

\begin{tabular}{|c|c|c|c|}
\hline Variabel & Indikator & No. Item & jumlah \\
\hline \multirow[t]{7}{*}{$\begin{array}{l}\text { Kecerdasan } \\
\text { Spiritual }\end{array}$} & $\begin{array}{l}\text { 1. Merasakan kehadiran } \\
\text { Allah }\end{array}$ & $1,7,27,15$ & 4 \\
\hline & 2. Berdzikir dan berdoa & $3,10,24,17$ & 4 \\
\hline & $\begin{array}{l}\text { 3. Memiliki kualitas } \\
\text { sabar }\end{array}$ & $2,9,25,18$ & 4 \\
\hline & $\begin{array}{l}\text { 4. Cenderung kepada } \\
\text { kebaikan }\end{array}$ & $5,12,23,16$ & 4 \\
\hline & 5. Memiliki empati & $4,11,22,19$ & 4 \\
\hline & 6. Berjiiwa besar & $6,14,21$ & 3 \\
\hline & $\begin{array}{l}\text { 7. Melayani dan } \\
\text { menolong. }\end{array}$ & $8,13,20,26$ & 4 \\
\hline & Total & & 27 \\
\hline
\end{tabular}

Akhlak

\begin{tabular}{|c|c|c|c|c|c|}
\hline \multirow{9}{*}{$\begin{array}{l}\text { Variabel } \\
\text { Akhlak }\end{array}$} & \multicolumn{3}{|c|}{ Indikator } & No Item & Jumlah \\
\hline & 1. & $\begin{array}{l}\text { Beribadah } \\
\text { Allah }\end{array}$ & Kepada & $23,16,22,19$ & 4 \\
\hline & 2. & $\begin{array}{l}\text { Berdzikir } \\
\text { Allah }\end{array}$ & Kepada & $5,12,8,13$ & 4 \\
\hline & 3. & Berdoa Kepada & Allah & $4,11,20,26$ & 4 \\
\hline & 4. & $\begin{array}{l}\text { Tawakkal } \\
\text { Allah }\end{array}$ & Kepada & $14,21,2,9$ & 4 \\
\hline & & $\begin{array}{l}\text { Tawaduk } \\
\text { Allah }\end{array}$ & Kepada & $6,25,18,28$ & 4 \\
\hline & 6. & Sabar & & $24,17,1,7$ & 4 \\
\hline & 7. & Syukur & & $27,15,3,10$ & 4 \\
\hline & & Total & & & 28 \\
\hline
\end{tabular}

Sumber: Jumlah kisi-kisi angket

Uji prasyarat analisis data menggunakan uji normalitas data, Data berdistribusi normal dapat dilihat dari nilai signifikansi atau nilai probabilitas. Dasar pengambilan keputuasan adalah jika nilai signifikan $<0,05$ data tidak normal dan sebaliknya jika nilai signifikansi > 0,05 data dikatakan normal (Suharsimi, 2006:216). Uji normalitas dengan menggunakan uji kolmogorov Smirnov. Uji normalitas dilakukan terhadap semua variabel, baik variabel terikat yaitu akhlak maupun variabel bebas yaitu kecerdasan emosional dan kecerdasan spiritual. Hasil uji normalitas diperoleh dengan bantuan perangkat lunak Statistical Paackage for Sevice Softition (SPSS).

Uji hipotesis menggunakan uji t dan anova dua jalur, uji t digunakan untuk menguji hipotesis pertama dan kedua, adapun uji anova dua jalur digunkana untuk menguji hipotesis ketiga. 


\section{Hasil dan Pembahasan}

\section{A. Temuan penelitian}

Penelitian ini dilakukan di SMP Negeri se-Kecamatan Sidoharjo, Penelitian ini termasuk penelitian kuantitatif. Penelitian ini mengangkat variabel penelitian yaitu variabel bebas Kecerdasan Emosional dan Kecerdasan Spiritual serta variabel terikat yaitu Akhlak Siswa. Penelitian ini, menggunakan rancangan analisis Univariat yaitu Two Way ANOVA atau Analisis Variansi (ANAVA) Dua Arah dengan desain Faktorial 2x2. ANAVA Dua Arah mempunyai pengertian sebagai analisis varian yang digunakan untuk menguji hipotesis perbandingan lebih dari dua sampel dan setiap sampel terdiri atas dua jenis atau lebih secara bersama-sama. Hasil pengolahan data dibantu menggunakan SPSS V20 untuk masing-masing variabel adalah sebagai berikut:

1. Kecerdasan Emosional $\left(\mathrm{X}_{1}\right)$

Data mengenai kecerdasan emosional diperoleh dari 22 butir instrumen. Sampel dalam penelitian ini berjumlah 221 siswa. Berdasarkan hasil olahan data tentang kecerdasan emosional, diketahui bahwa dari 221 siswa SMP Negeri se-Kecamatan Sidoharjo Kabupaten Sragen ada 102 siswa (46\%) memiliki kecerdasan emosional yang rendah, 119 siswa (54\%) memiliki kecerdasan emosional tinggi.

Langkah berikutnya adalah menentukan deskripsi dan analisis data. Deskripsi data disini dimaksudkan untuk mengetahui lebih lanjut hasil angket tentang kecerdasan emosional $\left(\mathrm{X}_{1}\right)$. Adapun hasil analisis dari kecerdasan emosional adalah nilai mean atau nilai rata-rata untuk skor kecerdasan emosional 66,081. Kemudian untuk standar deviasi untuk skor kecerdasan emosional 7,073.

\section{Kecerdasan Spiritual $\left(\mathrm{X}_{2}\right)$}

Data mengenai kecerdasan emosional diperoleh dari 27 butir instrument. Berdasarkan hasil olahan data tentang kecerdasan spiritual, diketahui bahwa dari 221 siswa SMP Negeri se-Kecamatan Sidoharjo Kabupaten Sragen ada 102 siswa (46\%) memiliki kecerdasan spiritual yang rendah, 119 siswa (54\%) memiliki kecerdasan spiritual tinggi.

Langkah berikutnya adalah menentukan deskripsi dan analisis data. Deskripsi data disini dimaksudkan untuk mengetahui lebih lanjut hasil angket tentang kecerdasan spiritual $\left(\mathrm{X}_{2}\right)$. Adapun hasil analisis dari kecerdasan emosional adalah nilai mean atau nilai rata-rata untuk skor kecerdasan emosional 81,312. Kemudian untuk standar deviasi untuk skor kecerdasan emosional 8,082.

\section{Akhlak (Y)}

Data mengenai akhlak diperoleh dari 28 butir instrumen Berdasarkan hasil olahan data tentang akhlak, diketahui bahwa dari 221 siswa SMP Negeri se-Kecamatan Sidoharjo Kabupaten Sragen ada 104 siswa (47\%) memiliki akhlak yang buruk, 117 siswa (53\%) memiliki akhlak baik.

Langkah berikutnya adalah menentukan deskripsi dan analisis data. Deskripsi data disini dimaksudkan untuk mengetahui lebih lanjut hasil angket tentang kecerdasan 
spiritual (Y). Adapun hasil analisis dari akhlak adalah nilai mean atau nilai rata-rata untuk skor akhlak 83,742. Kemudian untuk standar deviasi untuk skor akhlak 8,947.

\section{B. Pengujian Prasyarat Analisis}

\section{Uji Normalitas Data}

Uji normalitas dengan menggunakan uji Kolmogorov Smirnov. Uji normalitas dilakukan terhadap semua variabel baik variabel bebas kecerdasan emosional dan kecerdasan spiritual maupun variabel terikat yaitu perilaku keagamaan siswa SMP Negeri se-Kecamatan Sidoharjo Kabupaten Sragen. Kriteria pengambilan keputusan yakni jika nilai signifikansi > 0,05 maka data berdistribusi normal dan jika nilai signifikansi $<0,05$ maka data tidak berdistribusi normal.

Hasil uji normalitas data kecerdasan emosional diperoleh nilai signifikansi 0,17 dengan pengujian 0,05 maka $0,17>0,05$, sehingga data kecerdasan emosional berdistribusi normal. Selanjutnya, hasil uji normalitas kecerdasan spiritual diperoleh Data kecerdasan spiritual diperoleh nilai sig 0,11 dengan pengujian 0,05 maka 0,11 > 0,05 , sehingga data kecerdasan spiritual berdistribusi normal. Sementara itu, hasil uji normalitas akhlak diperoleh nilai signifikansi 0,6 dengan pengujian 0,05 maka $0,6<0,05$, sehingga data berdistribusi normal.

\section{Uji Homogenitas}

Uji homogenitas digunakan untuk mengetahui tingkat kesamaan varians antara dua kelompok untuk menerima atau menolak hipotesis dengan menggunakan uji univariat $\mathrm{F}$ melalui SPSS uji varian error yang menggunakan angka-angka Levene's Test of Equality of Error Variance dengan membandingkan nilai sig pada independent sample t test 0,05 ( sig $>0,05)$ dapat dikatakan homogen. Hasil uji homogenitas data kecerdasan emosional terhadap akhlak diperoleh nilai sig yaitu 0,33 dengan pengujian 0,05 , sehingga $0,33>$ 0,05 maka dapat disimpulkan data tersebut varian atau memiliki kelompok yang sama (homogen). Hasil uji homogenitas kecerdasan spiritual terhadap akhlak diperoleh nilai sig yaitu 0,17 dengan pengujian 0,05, sehingga 0,17 >0,05 maka dapat disimpulkan data tersebut varian atau memiliki kelompok yang sama (homogen). Hal tersebut sebagaimana sesuai dengan ketentuan pendapat Edi Riadi (2016:127).

\section{Pembahasan}

Penelitian yang dilaksanakan di SMP Negeri Se-Kecamatan Sidoharjo Kabupaten Sragen bertujuan untuk mengetahui perbedaan akhlak ditinjau dari kecerdasan emosional dan kecerdasan spiritual pada siswa kelas VIII di SMP Negeri Se-Kecamatan Sidoharjo tahun ajaran 2020/2021. Dalam melakukan pengujian hipotesis, peneliti menngunakan uji t untuk hipotesis yang pertama dan kedua, untuk hipotesis yang ketiga peneliti menggunakan uji anava dua jalur, uji t digunakan untuk menguji apakah ada perbedaan akhlak antara siswa yang memiliki kecerdasan emosional tinggi dan rendah, uji t digunakan untuk menguji apakah ada perbedaan akhlak antara siswa yang memiliki kecerdasan spiritual tinggi dan rendah. Untuk uji anava dua jalur digunakan untuk menguji perbedaan akhlak ditinjau dari interaksi antara kecerdasan emosional dan kecerdasan spiritual siswa. 


\section{Perbedaan Akhlak Antara Kecerdasan Emosional Tinggi dan Rendah Pada Siswa di SMP Negeri Se-Kecamatan Sidoharjo Tahun Ajaran 2020/2021}

Hasil penelitian dengan menggunakan Uji $t$ untuk hipotesis yang pertama menunjukan ada perbedaan akhlak antara kecerdasan emosional tinggi dan rendah diperoleh nilai sig. 0,000 dari pengujian 0,05. Sehingga sig (2-tailed) $0,000<0,05$ diperoleh $\mathrm{H} 01$ ditolak dan Ha1 diterima, maka ada perbedaan akhlak antara kecerdasan emosional tinggi dan emosional rendah. Hal ini menunjukan bahwa kecerdasan emoisonal tinggi berpengaruh terhadap akhlak siswa.

Dengan adanya hasil diatas, tingkat kecerdasan emosional siswa yang memiliki kecerdasan emosional tinggi dan kecerdasan emosional rendah memiliki perbedaan terhadap akhlak yang dimiliki oleh siswa, salah satu faktor yang mempengaruhi akhlak baik siswa adalah kecerdasan emosional yang tinggi, ketika siswa mempunyai kecerdasan emosional tinggi maka siswa tersebut memiliki pengelolaan emosi yang baik, rasa empati, kesadaran diri dan keterampilan social.

\section{Perbedaan Akhlak Antara Kecerdasan Spiritual Tinggi dan Rendah Pada Siswa di SMP Negeri Se-Kecamatan Sidoharjo Tahun Ajaran 2020/2021}

Hasil penelitian dengan menggunakan Uji t untuk hipotesis yang kedua menunjukan ada perbedaan akhlak antara kecerdasan spiritual tinggi dan kecerdasan spiritual rendah diperoleh nilai sig. (2-tailed) 0,000 dari pengujian 0,05 sehingga 0,000 $<0,05$ di peroleh H02 ditolak dan Ha2 diterima, maka ada perbedaan akhlak antara kecerdasan spiritual tinggi dan kecerdasan spiritual rendah. Hal ini menunjukan bahwa siswa yang memiliki kecerdasan spiritual tinggi akan berpengaruh terhadap akhlak siswa.

Kecerdasan spiritual siswa juga mempengaruhi akhlak, siswa dengan kecerdasan spiritual tinggi dengan siswa yang memiliki kecerdasan spiritual rendah mempunyai perbedaan akhlak, siswa yang memiliki kecerdasan spiritual tinggi mampu untuk merasakan kehadiran Allah, bersikap sabar, menentukan tindakan yang akan di ambil untuk memecahakan suatu permasalahan yang ada dengan tenang. Berbeda dengan seseorang yang memiliki kecerdasan spiritual rendah, cenderung bersikap acuh, tidak sabar, tidak memiliki rasa empati dan tidak suka menolong.

\section{Perbedaan Akhlak Ditinjau dari Interaksi Antara Kecerdasan Emosional dan Kecerdasan Spiritual Siswa di SMP Negeri Se-Kecamatan Sidoharjo Tahun Ajaran 2020/2021}

Hasil penelitian dengan menggunakan anava dua jalur untuk hipotesis yang ketiga, yaitu akhlak ditinjau dari interaksi kecerdasan emosional dan kecerdasan spiritual, dari perhitungan menggunakan SPSS V.20 diperoleh nilai Sig. 0.001 dari pengujian 0.05, sehingga sig. $0.001<0.05$ maka di peroleh keputusan H03 di tolak dan Ha3 diterima. Hal ini menunjukan bahwa terdapat perbedaan akhlak ditinjau dari interaksi antara kecerdasan emosional dan kecerdasan spiritual siswa.

Akhlak siswa dipengaruhi beberapa faktor, faktor internal dan eksternal, salah satunya adalah faktor internal yaitu kecerdasan, kecerdasan yang mempengaruhi akhlak adalah kecerdasan emosional dan kecerdasan spiritual, Setiap siswa memiliki kecerdasan emosional dan kecerdasan spiritual, ada yang memiliki kecerdasan emosional tinggi dan kecerdasan emosional rendah, begitu juga dengan kecerdasan spiritual, ada yang 
memiliki kecerdasan spiritual tinggi dan kecerdasan spiritual rendah. Untuk memiliki akhlak yang baik perlu dilatih untuk memiliki kecerdasan emosional tinggi dan kecerdasan spiritual tinggi.

\section{Kesimpulan}

Hasil analisis data penelitian tentang "Perbedaan Akhlak Di Tinjau Dari Kecerdasan Emosional Dan Kecerdasan Spiritual Siswa Siswa Smp Negeri Se Kecamatan Sidoharjo Tahun Ajaran 2020/2021" maka adapat disimpulkan :

1. Ada perbedaan akhlak antara kecerdasan emosional tinggi dan kecerdasan spiritual rendah, dilihat dari sig yang dihasilkan adalah sig. (2-tailed) 0,000 dari pengujian 0,05. Sehingga sig. (2-tailed) 0,000 $<0,05$ diperoleh H01 ditolak dan Ha1 diterima maka ada perbedaan akhlak antara kecerdasan emosional tinggi dan kecerdasan emosional rendah.

2. Ada perbedaan akhlak antara kecerdasan spiritual tinggi dan kecerdasan spiritual rendah, dilihat dari sig yang dihasilkan adalah sig. (2-tailed) 0,000 dari pengujian 0,05. Sehingga sig. (2-tailed) 0,000 < 0,05 diperoleh H02 di tolak dan Ha2 diterima maka ada perbedaan akhlak antara kecerdasan spiritual tinggi dan kecerdasan spiritual rendah

3. Ada perbedaan akhlak ditinjau dari interaksi kecerdasan emosional dan kecerdasan spiritual, dilihat dari sig yang dihasilkan adalah 0,001 dari pengujian 0,05. Sehingga $0,001<0,005$ diperoleh H03 ditolak dan Ha3 diterima maka ada perbedaan akhlak ditinjau dari interaksi kecerdasan emosional dan kecerdasan spiritual.

Dengan kesimpulan diatas pentingnya kecerdasan untuk menunjang akhlak siswa, baik kecerdasan emosional maupun kecerdasan spiritual, ketika siswa memiliki kecerdasan emosional tinggi maka besar harapan siswa tersebut memiliki akhlak yang baik, serupa dengan siswa yang memiliki kecerdasan spiritual tinggi maka siswa tersebut memiliki akhlak yang baik.

\section{Daftar Pustaka}

Arbabisarjou , Azizollah.dkk. 2016. Hubungan antara Kecerdasan Spiritual dan Kecerdasan Emosional di antara Mahasiswa Ilmu Kedokteran Universitas Isfahan dengan Konsentrasi pada Peningkatan Hubungan Sosial. Jurnal Internasional Penelitian Medis \& Ilmu Kesehatan

Basri, Hasan. 2013. Landasan Pendidikan. Bandung: CV Pustaka Setia.

Djazimi, Ma. 2016. Pengaruh Kecerdasan Emosional Terhadap Akhlak Siswa Madrasah Aliyah Al-Khairiyah Provinsi Banten. Studia Didkatika: Jurnal Ilmiah Pendidikan Vol. 10 No.2.

Edi Riadi. 2016. Statistika Penelitian: Analisis Manual dan IBM SPSS. Yogyakarta: Andi. Fauzy, Ichwan. Etika Muslim. Wisdom Science Sea 
Ginanjar ,Ary A, 2006. Rahasia Sukses Membangkitkan ESQ Power. Jakarta: Arga. . 2005. Rahasia Sukses Membangun Kecerdasan Emosi dan Spiritual ESQ Emotional Spiritual Quotient, THE ESQ WAY 1651 Ihsan 6 Rukun Iman dan 5 Rukun Islam. Jakarta: Arga Wijaya Persada.

Goleman, Daniel. 2005. Kecerdasan emosional untuk mencapai puncak prestasi, terj. Alex Tri Kantjono, Jakarta: P.T Gramedia Pustaka Utama

Kementrian Kebudayaan . 2014. Pendidikan Agama Islam, Jakarta:Kamdikbud.

Suardi, Moh. 2012. Pengantar Pendidikan: Teori Dan Aplikasi. Jakarta: PT indeks.

Sugiyono. 2015. Metode Penelitian Kombinasi (mixed methods). Bandung: Alfabeta.

Suharsimi Arikunto. 2006. Prosedur Penelitian: Suatu Pendekatan Praktik. Jakarta: PT Rineka Cipta.

Sumikan. 2011. Pengaruh Kecerdasan Emosional, Kecerdasan Spiritual an Prestasi Belajar PAI Siswa Kelas X SMK Negeri 1 Delanggu. Tesis pada UIN Maulana Malik Ibrahim

Syofian Siregar. 2017. Metode Penelitian Kuantitatif: Dilengkapi Dengan Perbandingan Perhitungan Manual\& SPSS. Jakarta: Kencana.

Triatna, Cepi dan Kharisma, Risma. 2008. EQ Power Panduan meningkatkan Kecerdasan Emosional. Bandung: Citra Praya.

Sudirman, 2020, realita yang terjadi di tempat penelitian tentang akhlak siswa. wawancara

Zohar, D. \& Marshall, I.N. (2005). Kecerdasan Spiritual (SQ) Memanfaatkan Kecerdasan Spiritual Dalam Berpikir Integralistik dan Holistik untuk Memaknai Kehidupan. Bandung: Mizan

Zulkifli, Muh. 2015. Pengaruh Kecerdasan Emosional dan Kecerdasan Spiritual Terhadap Prestasi Belajar Aqidah Akhlak Siswa Kelas Xi Madrasah Aliyah Kecamatan Suralaga.

Tesis pada UIN Sunan Kali Jaga 